Huszár Ágnes

\title{
A gender és a kommunikáció összefüggései: kommunikáció a munkahelyen A különbségek, avagy ki a jobb?
}

\author{
Ágnes Huszár: \\ The interconnection of gender and communication: communication in the workplace \\ The differences, in other words who is better?
}

\begin{abstract}
The paper explores the differences between the way women and men communicate. The author states that the communication skills of the two genders are different: women are better than men at performing various verbal tasks. The article reveals the possible causes of this difference in skills. Gender can define the communication style. We can also observe a difference in speech. There is an ever increasing demand for workers with excellent communication skills in the world of work. Such workplaces prefer to employ women rather than men. The better skills of women manifest themselves not only in mother tongue skills, but also in the acquisition of foreign languages. The author advises boys to communicate more emphatically and girls to be more assertive.
\end{abstract}

Key words: gender, communication, language skills, language learning, communication strategy

\section{ÖSSZEFOGLALÓ}

A cikk leírja a férfiak és nők eltérő kommunikációs szokásait. A szerző megállapítja, hogy a két nem kommunikációs képességei eltérőek: a nők bizonyos, verbalitással kapcsolatos feladatok megoldásában eredményesebbek a férfiaknál. Feltárja a különbségek lehetséges okait, ezek részben biológiai alapúak, részben a szociális neveléssel függnek össze. A gender meghatározza a kommunikációs stílust. Eltérés mutatkozik a két nem között a hangzó beszédben is. A munka világában egyre nagyobb szükség van a kiváló kommunikációs képességekre. A kommunikáció szempontjából igényes munkahelyeken szívesebben alkalmaznak nőket. A nők előnyei nem csak az anyanyelvben, hanem az idegen nyelvek elsajátításában is érvényesülnek. A szerző azt tanácsolja, hogy a fiúk kommunikáljanak empatikusabban, a lányok pedig legyenek asszertívebbek.

Kulcsszavak: gender, kommunikáció, nyelvi készségek, nyelvtanulás, kommunikációs stratégia

"Az asszonynak fegyvere a nyelve." (Magyar közmondás) "Elöbb szárad ki az Északi-tenger, mint egy nő kifogy a szóból." (Jütlandi közmondás) Számos hasonló bölcsesség idézhető nemcsak szólásokból, közmondásokból, hanem a Bibliából, Mohamed profétától és neves szerzőktől is. Bennük az a nézet fogalmazódik meg, hogy a nők jól, hatékonyan kommunikálnak, illetve sokat beszélnek. Érdemes a naiv nyelvészet téziseit a tudományos kutatás szigorú módszereivel megvizsgálni. Ha ezt megtesszük, akkor kiderül, hogy a fiúk és a lányok, a férfiak és a nők kimutatható, mérhető módon nem egyformán 
kommunikálnak. A lányok többsége megelőzi a fiúkat a beszédfejlődésben, hamarabb kezdenek el jól írni és olvasni. Ez a késleltetett fejlődés 10-12 éves korra általában kiegyenlítődik.

Hyde és Linn 1988-ban megjelent metaelemzése 165 amerikai vizsgálat, másfél millió embertől szerzett adati alapján megállapította: a nők bizonyos, verbalitással kapcsolatos feladatok (pl. fluencia, anagrammakészítés, esszéírás) megoldásában átlagosan eredményesebbek a férfiaknál. Az 1973 előtti vizsgálatok egyébként nagyobb különbséget mutattak a nők javára, mint a későbbiek. A különbségek azonban egyrészt nem mutatkoznak meg minden egyes verbális képesség tekintetében, másrészt csekélyebbek más, pl. matematikai, térérzékelési feladatban tapasztaltaknál. Ezeken a területeken a férfiak átlaga jóval eredményesebb a nők átlagánál.(Hyde-Linn 1988)

\section{A KÉPESSÉGEKBEN MEGMUTATKOZÓ KÜLÖNBSÉGEK}

Ezeknek a különbségeknek a magyarázatához segítségül hívjuk a férfiak és a nők viselkedését vizsgáló tudományok segédfogalmait, a biológiai nemet (szexus) és a társadalmi nemet (gender). Ez az eredetileg a pszichoanalitikus Robert Stollernek egy 1968-ban megjelent írásából származó különbségtevés fontos mankónak bizonyul a nők és a férfiak eltérő viselkedésének tudományos megismerésében.

A verbális feladatokban kimutatható különbség egy része a biológiai nemhez (szexus) kötődik. A nemi fejlődés megindulása genetikai szinten van a „testünkbe írva” a kromoszómák által. A biológiai nem már a fogantatás pillanatában eldől. A két nem genetikai állománya eltér, a férfiak 23. kromoszómapárja ugyanis XY, a nőké XX kromoszómákból áll. Ez a genetikai diszpozíció indítja be a hormonális fejlődést, a másodlagos nemi jegyek kialakulását. Sajnos a nemi fejlődés nem mindig zajlik le ilyen harmonikusan. Zavarok léphetnek fel benne, ezek egyike az androgénérzéketlenség. Az ilyen, genetikailag fiúnak tekinthető - XY kromoszómájú - gyermekek szervezetében termelődik ugyan a férfiakra jellemző hormoncsoport, de mivel hiányoznak a megfelelő receptorok, nem tudnak hatni a sejtekre. Ennek következtében lánynak látszanak, de sem méhük, sem petefészkük nincsen. Egy másik fejlődési rendellenesség - az úgynevezett kongenitális adrenális hiperpláziamindkét nemú gyerekeket sújthatja. Szervezetük túlságosan sok androgént termel, ezért a genetikailag lánynak tekinthető - XX kromoszómájú - gyerekek is fiús külsejúnek serdülnek fel.

Azoknál a gyermekeknél is vannak különbségek, akiknél efféle zavar kizárható. A fiúknál gyakoribb a megkésett beszédfejlődés, a dadogás és a diszlexia. Két harvardi neurológus, Galaburdia és Geschwind az eltérést az embrionális életben végbemenő agyi fejlődés különbségére vezeti vissza. A terhesség tizedik és a tizennyolcadik hete közötti időszakban a magzat agya viharos gyorsasággal kezd növekedni. Kísérletek bizonyítják, hogy a bal agyfélteke valamivel lassabb ütemben fejlődik, mint a jobb, ezért az tovább sebezhető marad, kevésbé tud azoknak a káros hatásoknak ellenállni, amelyek a méhen belül érik. A lehetséges káros hatás a magzat heréinek kialakulása idején a testben keringő férfi tesztoszteron hormon. A magas tesztoszteronszint gátló hatással van a kéreg növekedésére. A két agyfélteke fejlődésének eltérő sebessége miatt a baloldalra gyakorolt hatás súlyosabb lehet a jobb oldalinál. Ez a magyarázat a nőknek a beszédképességekben megmutatkozó előnyét tehát a fiúk szempontjából „rosszul időzített” hormonális hatásra vezeti vissza. (Huszár 2009)

\section{A KOMMUNIKÁCIÓS STílUS ALAPVETŐ ELTÉRÉSEI}

Ezt viszont a társadalmi nemhez (gender) kapcsolódó viselkedési repertoár határozza meg. A biológiai nemre ráépülő viselkedésmód az, ami bennünket igazán férfivá és nővé tesz. $\mathrm{A}$ társadalmi nem (gender) a társadalom által elvárt "nőies", "férfias" viselkedési mód. Ezt a 
szereprepertoárt nevelődésünk során sajátítjuk el, vagy sajátíttatja el velünk a média, az iskola, a kortárs csoportok. A társadalmi nemhez kapcsolódó szereprepertoár gyökeresen különbözik egymástól az eltérő társadalmakban. Ugyanazon a társadalmon belül is sokat változik a történelmi, gazdasági és politikai folyamatok következtében. A nyugati típusú társadalmakban egyfajta egységesülésnek, uniszex tendenciának lehetünk tanúi. A moszlim világban a női és férfi repertoár radikálisan különbözik egymástól. A transzkulturális hatások következtében ezek az eltérő szereprepertoárok nem különülnek el egymástól úgy a térben és időben, mint régen, a magyar városokban nemcsak nyugati típusú és viselkedési emberrel, hanem szigorúan lefátyolozott moszlim nőkkel is találkozhatunk.

A női viselkedésről általánosságban elmondható, hogy a nők jobb kapcsolatteremtő, empatikus készségel rendelkeznek, hangképzésük tisztább, intonációjuk színesebb, nyelvhasználatuk normakövetőbb, mint a férfiaké, és csakugyan többet beszélnek, mint ők. A Brit Nemzeti Szövegtár (British National Corpus) számára gyújtött felmérésben a nők körülbelül másfélszer annyi szót használtak, mint a férfiak. A nyelvhasználat - az anya- és az idegen nyelv használata szempontjából kardinális kérdés a hangzó beszéd: ennek alapján ítélnek meg bennünket. (Huszár 2009)

\section{NEMI KÜLÖNBSÉGEK A HANGZÓ BESZÉDBEN}

Ezek egy része, pl az alaphangmagasság biológiailag motivált, ugyanis a férfiak hangszálai vastagabbak $(21-27 \mathrm{~mm})$, mint a nőké (17-26). A rés nagysága befolyásolja a rajta áttóduló levegőoszlop rezgését, ennek következtében pedig a beszédhang alaphangmagasságát. Minél hosszabb a rés, annál mélyebb a hang. A férfiak hangjának alaprezgése: 100-200 Hz, a nőké: 150-300. A magyar férfiak alaphangmagassága: $103 \mathrm{~Hz}$, a nóké: $184 \mathrm{~Hz}$, ez lényegesen mélyebb, mint a spanyol, francia, lengyel vagy orosz nőké. A spanyol nők alaphangmagassága például ötven $\mathrm{Hz}$-cel magasabb, ez nagyon jól hallható különbség. A magyar férfiak átlagos alaphangmagasság-magassága $103 \mathrm{~Hz}$. A spanyol férfiaké ezt például jóval meghaladja, $130 \mathrm{~Hz}$.

Ha korán megtanulunk egy idegen nyelven beszélni, az alaphangmagasság még beállítható, több nyelvre is. Később, 20 éves korban ez szinte lehetetlen.

A nők és a férfiak beszéde a tempó tekintetében eltérő. A nők általában valamivel gyorsabban beszélnek, mint a férfiak. Ez megfigyelhető különféle anyanyelvú beszélőknél. A magyar nők átlagban szintén gyorsabban beszélnek, mint a férfiak. Az egyéni eltérések azonban számottevők lehetnek.

Másik eltérés a két nem beszéde között az, hogy a férfiak beszéd közben többet hezitálnak, mint a nők. Szakszerűen úgy mondjuk, hogy ők több kitöltött szünetet alkalmaznak, mint a nők. A beszéd közben hallható $\mathrm{mmm}$, ööö hanghatásokat nevezzük kitöltött szünetnek.

A nőkre jellemző ezen kívül az úgynevezett “levegős ejtés" és a nagy amplitúdójú intonációs ívek használata.

\section{A MUNKA VILÁGA EGYRE KOMMUNIKÁCIÓ-IGÉNYESEBB}

Mindennapi tapasztalatunk, hogy egyre fontosabb a kommunikáció a mindennapi életben és egyre inkább felértékelődnek a kommunikációs képességek a munka világában is. A hagyományos nagyipar és mezőgazdasági nagyüzemek átalakulásával egyre kevesebb azoknak a száma, akik munkaidejük során szinte kizárólag megmunkálandó munkadarabokkal vagy termékek előállításával foglalkoznak. A taylorista munkaszervezés kifejezetten tiltotta a beszélgetést munkavégzés közben. A kisebb termelői egységben dolgozóknak újabban azonban egyre inkább szerepet kell vállalniuk olyan tevékenységekben, amelyek jó kapcsolatfelvevő és kapcsolattartó, úgynevezett szociális és kommunikációs képességek mozgósítását kívánják meg. Ezzel összefüggésben felértékelődnek az egyes 
szakmákhoz kapcsolódó szociális kompetenciák, egyre több értelmiségi és szolgáltató jellegú szakma kommunikációigénye vált nyilvánvalóvá.

Vannak szakmák, melyek esetében a jó kommunikációs készség - legalább elvárásként - mindig is hozzátartozott a pályaalkalmassághoz. A jogász végzettséghez kötött szakmák gyakorlóinak, elsősorban az ügyészeknek és az ügyvédeknek mindig is ismerniük kellett a verbális bizonyítás, a cáfolás, a hiteles és meggyőző érvelés technikáját. Azt sem vitatja senki, hogy a pedagógusok kultúraközvetítő szerepüknek csak magas fokú kommunikációs hatékonysággal képesek jól megfelelni. Még érvényesebb ez arra a nevelési feladatra, amely az óvónő, tanító és tanár mindennapi tevékenysége.

Más szakmák kommunikációigényessége nem tűnik ennyire nyilvánvalónak. A gazdasági élet magas szintú szereplőinek, a menedzsereknek pályaalkalmasságát első sorban szervezésre, vezetésre és döntésre vonatkozó tudásuk és képességeik alapján szokták megítélni. A kommunikációs készségek ezekhez képest másodrendűnek túnnek. Az újabb kutatások árnyalják ezt a képet. Időmérleg-vizsgálatok mutatják, hogy a menedzserek munkaidejük 75 százalékát verbális tevékenységre fordítják. Ez nem is annyira meglepő, ha belegondolunk, hogy a kereskedelemben és az üzleti életben a sikeres kommunikáció a gazdasági siker alapfeltétele lehet.

Vannak aztán olyan új foglalkozások elsősorban a média és az arculatalkotás területén -, melyeknek képviselői munkaidejük jó részében kommunikációs feladatokat oldanak meg. Munkájuk minőségét elsősorban azon mérik le, mennyire jól képesek alkalmazkodni a nyelvi piachoz. Ezeknek a szakmáknak a gyakorlóit a nyelv technikusainak is nevezik.

A globalizáció következtében egyre több olyan munkahely jött létre, amelyek a munkavállalótól minimális speciális szaktudást, viszont kiemelkedő kommunikációs képességeket kívánnak meg. Ezeken a szolgáltató szférában létesülő munkahelyeken a munkavállaló úgy végzi a szolgáltatást, hogy csak telefonon érintkezik a szolgáltatást igénybe vevő ügyféllel. Feladata információ kérése (pl. közvélemény-kutatás) vagy annak adása (ügyfélszolgálat). A globalizáció következtében egyre több olyan munkahely jött létre, amelyek a munkavállalótól minimális speciális szaktudást, viszont kiemelkedó kommunikációs képességeket kíván meg. A call centerek dolgozói számára a munkavégzés egyenlő a kommunikációval. Menedzsereik előnyben részesítik a nőket jobb kommunikációs készségük, tájnyelvi elemektől mentes, tisztább hangképzésük miatt.

De másféle munkahelyeken és a hierarchia különböző szintjein is jól teljesítenek a nők. Janet Holmes (Wellington Language in the Workplace Project, rövidítve: LWP). Az újzélandi wellingtoni egyetemen 1996 és 2003 között zajló, a szerző által irányított gyújtőmunka során huszonkét munkahelyen gyưjtöttek, több, mint 500 személytől került a korpuszba spontán beszédanyag. (Huszár 2009)

Bebizonyosodott: a nők hajlamosabbak a demokratikus munkastílusra, de parancsolni is tudnak (fönök - beosztott viszony).

\section{ANYANYELVI ÉS IDEGEN NYELVI KOMMUNIKÁCIÓ}

A nők elónyei nemcsak az anyanyelvben érvényesülnek, hanem az idegen nyelvek elsajátításában is. Az anyanyelv elsajátításnak létezik egy kritikus időszaka, ha ezen belül nem indul be - nincs a külvilágból megfelelő impulzus -, akkor ez később alig korrigálható. Az első biológiai sorompót 6-7 éves korra teszik, a másodikat 13 éves korra. A második biológiai határt fontos az idegen nyelvek elsajátításában is: csak akkor leszünk képesek az idegen nyelv akcentusmentes elsajátítására, ha ennek mélyreható hatása 13 éves kor előtt ér bennünket.

$\mathrm{Az}$ anyanyelv-tanulási időszak: -5 hónap 11 év (ebbe több nyelv is beleeshet, pl. szülők nyelve + környezet nyelve). A méhen belüli fejlődés második szakaszában a magzat már hall, így képes környezete hanghatásainak, pl. a környezet alaphangmagasságának a 
befogadására. A beszédtanulás nagyon gyorsan zajlik; fontos, hogy a gyermek öt-hatéves korára megfelelő szókinccsel és a szintaktikai szabályok ismeretével rendelkezzék, beszédprodukciója és beszédértése fejlett legyen, csak így lesz képes az iskolai követelményeknek megfelelni. A beszédképesség elválaszthatatlan a gondolkodás fejlettségétől: ezért alkalmaznak az iskolaérettségi tesztek olyan feladatokat, amelyek egyszerre mérik mind a kettőt, pl. tedd a piros korongot a kék kocka mellé, alá, rá stb.

$\mathrm{Ha}$ valaki két- vagy többnyelvú környezetben nő fel, az így megszerzett nyelvtudást is ápolni kell, pl. nem a környezet nyelvének megfelelő iskoláztatással. A kisgyerek szókincse párezer, ezt szükséges fejleszteni.

$\mathrm{Az}$ idegennyelv-oktatásnak építenie kell az anyanyelv-elsajátítás elemeire, ezen mindenekelőtt a kreativitás felhasználását értem. Van egy gyakran hallható előítélet: az idegennyelv-tudás fölöslegesen terheli meg a gyermeket, nem jut agyi kapacitása az anyanyelvre, ill. más fontos ismeretekre.

Csakugyan elmarad egy kicsit a kétnyelvú, föleg akkor, ha a gyengébb nyelvén iskoláztatják, de ezt hamar behozza. Fontos előny viszont az így megszerzett kognitív rugalmasság. Utána, a gyermeknél 7-10 éves kortól, a nyelvi tudatosság beérésétől kezdve az intézményes nyelvoktatás a hatékony, illetve a spontán nyelvtanulás irányítása szakember (tanár) segítségével.

A biológiai diszpozíció és a szociális tanulás alapján észrevehető a nők előnye. $A z$ extrovertált beállítottságú emberek szintén előnyben vannak a nyelvtanulás során. A nők nyelvtanulási előnyét elősegíti a spontán kommunikációigény (külföldi barátok), az ügyesebb utánzókészség (Pygmalion-hatás), és a nagyobb szorgalom.

Ma Magyarországon több nő rendelkezik érvényes nyelvvizsgával és valódi nyelvtudással, mint férfi.

TANULJUNK MEG ÚGY BESZÉLNI, AHOGY A NŐK?
Ezzel a címmel jelennek meg tanácsadó könyvek Amerikában. A fiúk és a lányok eltérő kommunikációs stratégiái kisgyermekkortól kezdve determinálják a kapcsolatépítés sikerességét (Tannen-kísérlet). A nők általában ügyesebbek a kommunikációs események alakításában. Jobban tudják közvetíteni testtartással, mozgásokkal, szemkontaktussal partnerük felé az üzenetet: figyelek rád, fontos vagy nekem, érdekel, amit mondasz. Ez nem magától alakul így ki, hanem hosszú tanulási folyamat eredményeként, ezt például Deborah Tannen 1996-os kutatásából tudhatjuk. Ő azonos nemú párok, barátok és barátnők beszélgetését vizsgálta filmfelvételek segítségével. A legfiatalabbak nyolc, a legidősebbek huszonöt évesek voltak. A fiúk és a lányok viselkedésében különbségek mutatkoztak mind magának a beszélgetésnek a lefolytatásában, mind az ezt kísérő egyéb kommunikációs jelzéseknek a tekintetében. A lányok már kezdettől fogva egymás felé fordulva, gyakran egymás szemébe nézve beszélgettek. A fiúk kezdetben feltúnően kerülték az intim tér kialakítását, keveset néztek egymásra, gesztusokat tettek az ellenkező irányba, mintha csak véletlenül kerültek volna egymás mellé. Kamaszkorukban ez változott, akkor kezdtek megjelenni az egymásra való figyelés nem-verbális elemei. A lányok a kommunikációs stílus tekintetében felnőttes mintát követtek, mondhatjuk úgy is, hogy kevés a tanulnivalójuk. A mintában szereplő fiatal férfiak viszont sokat fejlődtek kommunikációs tekintetben a fiúkhoz képest. Bármilyen furcsán hangzik is: kommunikációjukban közelítettek a női stílushoz. (Tannen 2003)

Ez kihat az idegennyelv-oktatás sikerességére is. A megoldás olyan elemek beépítése a nyelvoktatásba, amelyek kimozdítják a fiúkat sztereotípikus szerepeikből (hallgatás, kompetitív viselkedés) és elindítja őket egy empatikusabb kommunikáció útján. $\mathrm{A}$ lányok esetében fontos az asszertív (nyelvi) viselkedés előmozdítása. 
Huszár Ágnes: A gender és a kommunikáció összefüggései: kommunikáció a munkahelyen

Szokjanak le pl. arról, hogy állandóan elnézést kérjenek. A lehetséges módszerek, például:

másik fél oldaláról, csoportépítés szerepjátékok fordított szereposztásban, konfliktusszituációk megoldása az egyik és a

mozaikmódszerrel (Aronson).

A cél az, hogy legyen öröm a kommunikáció.

Keressük a flow-érzést

(Csíkszentmihályi Mihály).

\section{SZAKIRODALOM}

[1] Gocsál Á., Huszár Á. (2006): A spontán beszéd és a hangos olvasás időszerkezetének összehasonlítása férfi és női beszélők esetén. In: Modern Nyelvoktatás XII. 3/4:37-47.

[2] Herring, S. C. (2013): Gender és hatalom az online kommunikációban. In: Juhász Valéria, Kegyes Erika (szerk.) Társadalmi nem és nyelvhasználat. Válogatott tanulmányok az angol és német szakirodalomból. Szeged: Szegedi Egyetemi Kiadó. 219-242.

[3] Huszár Á. (2009): Bevezetés a gendernyelvészetbe. Miben különbözik és miben egyezik a férfiak és a nök kommunikációja és nyelvhasználata? Budapest: Tinta Könyvkiadó.

[4] Hyde, J. - S. Linn, M. C. (1988): „Gender Differences in Verbal Ability: A Metaanalysis.” In: Psychological Bulletin v. 104. 53-69.

[5] Tannen, D. (2003): Gender and Family Interaction. In: Holmes, J., Meyerhoff, M. (ed.) (2003) The Handbook of Language and Gender. Blackwell 179-201. 